\title{
Impact of Training Programmes on Vermi Compost Trainees
}

\author{
M. V. Tiwari*, V. K. Poshiya and P. D. Verma \\ KVK, Dediapada, NAU, Narmada, India \\ *Corresponding author
}

Keywords

Vermi compost technology, Training, Impact assessment

Article Info

Accepted:

25 November 2020

Available Online:

10 December 2020

\section{A B S T R A C T}

The study was undertaken in Narmada district of Gujarat. The findings reveal that seventy five trainees were imparted training on vermicompost technology by conducting two vocational training courses. In order to evaluate these training programmes, present study was undertaken to find out impact assessment of the participants and suggestions from the trainees in order to bring improvement in the coming training courses. It was found that majority of respondents joined the training course to adopt vermin compost technology as an occupation and only 10.5 percent joined training course just to get certificate of training. More emphasis on practical classes, supplying of printed material and wide publicity were three suggestions given by the participants for bringing improvement in future programmes.

\section{Introduction}

Vermi composting is the process of producing organic fertilizer or the vermin compost from bio-degradable materials with earthworms. Composting with worms avoids the needless disposal of vegetative food wastes and enjoys the benefits of High quality compost. Vermiculture is environment friendly since earthworms feed on anything that is biodegradable, vermicomposting then partially aids in the garbage disposal problems. No imported inputs required, worms are now locally available and the materials for feeding are abundant in the locality as market wastes, grasses, used papers and farm wastes. It is also highly profitable, both the worms and castings are saleable (www.bpi.da.gov.ph, 2010). Vermicompost does not have any adverse effect on soil, plant and environment. It improves soil aeration and texture thereby reducing soil compaction. It improves water retention $n$ capacity of soil because of its high organic matter content. It also promotes better root growth and nutrient absorption and improves nutrient status of soil, both macronutrients and micro-nutrients (Punjab State Council for Science and Technology, 2010). 
The main objectives of this study to test the impact assessment of vermin-compost trainees.

\section{Materials and Methods}

The present study was conducted in KVK, Narmada. Total sample size of 75 respondents. A questionnaire was formulated comprising of general information, background of participants landholding etc. A pre test was conducted to know the level of knowledge of participants regarding vermin compost, method and preparation etc.. To test the impact assessment of trainees, a set of 11 questions related to importance and use etc. were used. Hence, impact assessment was calculated from the difference of scores obtained likewise, the suggestions from the trainees were recorded for bringing further improvement in the training. The data were tabulated and analyzed using frequency, percentages and ranking.

\section{Results and Discussion}

The results obtained from the present investigation as well as relevant discussion have been summarized under following heads:

\section{Socio-economic Profile of Trainees}

The participants differed in age, education, occupation and landholding. The data (Table 1) showed that the age of participants was between 20 to 68 years. More than half of trainees were in age group of 31-40 whereas 20.0 per cent were above 40 years of age. Information with respect to caste showed that participants irrespective of caste system were involved in the training. Assessment of the trainees with respect to education indicated that 40.0 per cent studied up to primary followed by matriculate level (26.6\%) and middle level (13.3\%). More than half of trainees belonged to farming background and only 4.0 per cent belonged to service class. It was also inferred (Table 1) that 46.6 per cent farmers were having large land holding whereas few farmers (4.0\%) were small landholders. Further, marginal and landless farmers want to adopt this technology thus it was evident that vermin compost technology does not require much land and therefore, landless farmers were found to be interested to adopt this technology to supplement their family income.

\section{Reasons of participation}

The factors which motivated the respondents to join the training course were given for ranking in order of importance as perceived by them. As

shown in the table 2, 60.0 per cent respondents joined training course to adopt vermi compost as an occupation to produce organic manure 14.6 per cent wanted to learn about vermin compost techniques for production of organic manure and 10.6 per cent joined the training course just to know the its importance for soil health followed by 6.6 percent participants attended training just to get the certificate of training. Lesser participants showed their interest to establish linkage with university, knowledge about vermin compost and to teach fellow farmers about method of vermin compost production. Similar results were also reported by Patel.et.al (2015) there is a need to organize training for the tribal farmers regarding vermicompost technology by the extension agency working in the area.

The suggestions offered by the trainees for further improvement of the training course were presented in table 3 . 
Table.1 Socio-economic profile of trainees

\begin{tabular}{|c|c|c|c|}
\hline & & & $(n=75)$ \\
\hline S. No. & Particulars & Frequency & Percent \\
\hline \multirow[t]{4}{*}{1.} & \multicolumn{3}{|c|}{ Age } \\
\hline & Up to $30 \mathrm{yrs}$ & 35 & 46.6 \\
\hline & $31-40$ yrs & 25 & 33.3 \\
\hline & Above 40 yrs & 15 & 20.0 \\
\hline \multirow[t]{4}{*}{2.} & \multicolumn{3}{|c|}{ Caste } \\
\hline & Scheduled caste & 67 & 89.3 \\
\hline & Backward Caste & 5 & 6.6 \\
\hline & Others & 3 & 4.0 \\
\hline \multirow[t]{7}{*}{3.} & \multicolumn{3}{|c|}{ Education } \\
\hline & Primary & 30 & 40.0 \\
\hline & Middle level & 10 & 13.3 \\
\hline & Matriculate & 20 & 34.6 \\
\hline & Senior Secondary & 8 & 10.6 \\
\hline & Diploma holder & 4 & 5.3 \\
\hline & Graduate & 3 & 4.0 \\
\hline \multirow[t]{6}{*}{4.} & \multicolumn{3}{|c|}{ Occupation } \\
\hline & Farming & 46 & 61.3 \\
\hline & Business & 14 & 18.6 \\
\hline & Service & 3 & 4.0 \\
\hline & Housewife & 5 & 6.6 \\
\hline & Others (Retiree, student) & 7 & 9.33 \\
\hline \multirow[t]{7}{*}{5.} & \multicolumn{3}{|c|}{ Landholding } \\
\hline & Landless & 0 & 0 \\
\hline & Marginal (<1 ha) & 7 & 9.33 \\
\hline & Small (1-2 ha) & 3 & 4.0 \\
\hline & Semi medium (2-4 ha) & 10 & 13.3 \\
\hline & Medium (4-10 ha) & 15 & 20.0 \\
\hline & Large $(>10 \mathrm{ha})$ & 35 & 46.6 \\
\hline
\end{tabular}


Table.2 Reasons of participation in training programme in vermicopost cultivation.

\begin{tabular}{|c|c|c|c|}
\hline Sr. No. & Reasons & Number & Percentage \\
\hline $\mathbf{1 .}$ & To adopt vermin compost as an enterprise & $\mathbf{4 5}$ & $\mathbf{6 0}$ \\
\hline $\mathbf{2 .}$ & $\begin{array}{c}\text { To learn about vermin compost method to } \\
\text { produce organic manure }\end{array}$ & $\mathbf{1 1}$ & $\mathbf{1 4 . 6}$ \\
\hline $\mathbf{3 .}$ & Just to know about vermin compost good for \\
soil health & $\mathbf{8}$ & $\mathbf{1 0 . 6}$ \\
\hline $\mathbf{4 .}$ & To get certificate of training course & $\mathbf{6}$ & $\mathbf{6 . 6}$ \\
\hline $\mathbf{5 .}$ & To establish linkage with university & $\mathbf{4}$ & $\mathbf{5 . 3}$ \\
\hline $\mathbf{6 .}$ & To teach fellow farmers about vermin compost \\
process & $\mathbf{2}$ & $\mathbf{2 . 6}$ \\
\hline
\end{tabular}

Table.3 Suggestions given by the trainees

\begin{tabular}{|c|c|c|c|}
\hline \multicolumn{4}{|c|}{$(\mathrm{n}=75)$} \\
\hline S.No. & $\begin{array}{c}\text { Suggestion } \\
\mathbf{1 .}\end{array}$ & $\begin{array}{c}\text { Frequency } \\
\text { Ganking }\end{array}$ & I \\
\hline $\mathbf{2 .}$ & $\begin{array}{c}\text { Supply printed inftrations } \\
\text { Demontics materials }\end{array}$ & 39 & II \\
\hline $\mathbf{3 .}$ & $\begin{array}{c}\text { Give wide publicity on vermicompost as } \\
\text { organic manure }\end{array}$ & 30 & III \\
\hline $\mathbf{4 .}$ & Organize training at different out stations of the \\
KVK & 27 & IV \\
\hline $\mathbf{5 .}$ & Increased duration of training & 17 & V \\
\hline
\end{tabular}

The results showed that more importance to front line demonstrations, supply of printed materials and wide publicity on vermin compost were the main suggestions as more than 39 per cent participants viewed that by applying these suggestions, trainees might got knowledge regarding required information for vermicompost production with more satisfaction level that would be beneficial to start and flourish organic manure enterprise in future. Besides these suggestions, 27 per cent respondents also gave stress on Organize training at different out stations of the KVK followed by 17 percent increase duration of training,

Good conduct of training provide trainees needed information and guidance to start and flourish any enterprise. Vermicompost technology is such an enterprise in which requirement of land is not a big issue so even landless farmers can augment their income through vermicopost.

\section{References}

Bhimawat BS, Punjabi NK and singh Karan (2008). Adoption of vaemiculture technology by tribal farmers in Udaipur district famer iof Rajasthan, International Journal of Rural of Studies (IJRS), vol. 15 (1): 1.3

Kaur, P (2002). Evaluation of vermiculture technology transfer programme among rural women in terms of knowledge and adoption. M.Sc. Thesis MPUAT, Udaipur Campus H.Sc., Udaipur. 


\section{How to cite this article:}

Tiwari, M. V., V. K. Poshiya and Verma, P. D. 2020. Impact of Training Programmes on Vermi Compost Trainees. Int.J.Curr.Microbiol.App.Sci. 9(03): 3575-3579. doi: https://doi.org/10.20546/ijcmas.2020.912.425 